\title{
Noise Monitoring, Mapping, and Modelling Studies - A Review
}

\author{
Pervez Alam ${ }^{1 *}$, Kafeel Ahmad', Shakil S. Afsar ${ }^{1}$, Nasim Akhtar ${ }^{2}$ \\ 1 Department of Civil Engineering, Jamia Millia Islamia, 110025, New Delhi, India \\ 2 CSIR, CRRI, Mathura Road, New Delhi, India \\ * Corresponding author's e-mail: pervezjmi@gmail.com
}

\begin{abstract}
This paper reviews the literature on noise monitoring, noise mapping and noise modeling studies carried out in different countries by many researchers. The article reveals the current status of the noise-related studies and noise mapping studies. It was discovered that $90 \%$ of the noise monitoring studies were focused on the traffic noise, while the remaining $10 \%$ focused on the residential, commercial and industrial areas. Sometimes, there may be a necessity to analyze the sound pressure levels all over the place, or around a particular piece of land and machinery of industry. Researchers have used the noise monitoring data for the development of 2D and 3D noise maps which gives a clear picture of the noise level around the source of noise in $\mathrm{X}, \mathrm{Y}$, and $\mathrm{Z}$ direction. For taking a decision regarding the noise level for any development project, predicting the noise level is always necessary. The traffic noise models are generally used for the purpose of prediction. Early models are based on constant vehicle speed, later some models predicted the noise level for interrupting the traffic flow. For instance, the Stop and Go model can be used for the prediction of the noise level in an interrupted flow. Four such models were reviewed and compared in this article.
\end{abstract}

Keywords: noise mapping, noise monitoring, noise modelling, CoRTN, FHWA

\section{INTRODUCTION}

Today, the noise pollution is one of the principal types of urban natural contamination. What is more, it is responsible for the negative effects that are harmful to the Earth and the personal welfare of the people. The increase in noise pollution relies upon numerous elements and in addition, they increase in the urban population and thus the expansion in the number of development exercises and vehicles [Directive EP, 2002]. Noise pollution can be considered as one of the significant toxins present in urban areas. Its assessment, control, and decrease are among the major natural well-being concerns for specialists [Mohammadi, 2009; Zannin, et al., 2013]. Many researchers have also reported that road traffic is the most general and prominent noise pollution source in the developing countries [Mocuta, 2012]. Some researchers from different countries also investigated and characterized noise pollution under different types of traffic conditions [Boer, 2007; Stoilova and Stoilove, 1998, Zannin, et al., 2003;
Piccolo, et al., 2205; Zannin, et al., 2006]. The increase in noise pollution is not sustainable because it involves direct, but also cumulative, adverse health effects. It also harmfully affects the future generations and has socio-cultural, aesthetic and economic effects. Noise monitoring under different road and environment condition is one of the best tools to discover the critical locations in residential, commercial and industrial areas [Akhter, et al., 2016]. In order to develop an acoustic model, it is necessary to know as many details as possible [Iliescui, et al., 2015]. The traffic noise prediction models are required to assist in the design of highways and roads and sometimes, in the evaluation of the existing or planned changes in the traffic noise conditions. Normally, for prediction of the sound pressure levels, the noise levels in terms of Leq are required by most of the sound prediction models [Steele, 2001]. The results from the noise prediction model may further be used for the development of $2 \mathrm{D}$ and 3D noise maps [Stoter, et al., 2008]. Noise mapping is the graphic representation of the sound 
level distribution existing in a given region and environmental condition, for a defined period of time. Noise mapping is broadly divided into two categories i.e., 2D and 3D. The 2D mapping has been extensively and successfully used for environmental impact studies like Air pollution, Soil pollution and Noise in the existing environment. Noise monitoring, mapping, and modeling studies are interrelated. The results of noise monitoring can be used for the prediction of the sound pressure level employing different prediction models; the predicted results may further be used for the development of noise maps.

\section{NOISE MONITORING STUDIES IN DEVELOPING COUNTRIES}

Significant negative effects on the children's blood pressure and mental health due to noise pollution have been found. Some studies show that the people who are exposed to high street traffic noise levels often suffer from hypertension [Chang, et al., 2011]. The noise monitoring studies are especially needed for monitoring the sound levels and appropriate reduction measures can be implemented to control the noise pollution [Garg, et al., 2017]. Studies on monitoring and applying noise abatement measures to ambient noise and controlling them have been conducted in various parts of the world. The advancement of developing countries is accompanied by industrialization. We see not only a higher level of noise in industry and traffic, but also a concentration of population, on the one hand, and a higher construction of high rise buildings on the other [Barrekette, 1973]. The noise monitoring studies of 22 developing countries and 25 cities for two decades were reviewed to demonstrate the current state of the investigation on the acoustic pollution in developing countries and the gaps in the studies. Table 1 shows the maximum, equivalent and minimum noise level of developing countries. A noise monitoring study was performed by [Chowdhury, et al., 2010] at Dhaka city of Bangladesh. The monitoring results show a maximum noise level of $87 \mathrm{~dB}(\mathrm{~A})$ and Leq of $82 \mathrm{~dB}(\mathrm{~A})$ is enough to create discomfort for the people living in the nearby areas. A study conducted in China, Brazil, Egypt, and Iraq [Bengang, et al., 2002; Henrique, et al., 2002; Zekry and Ghatass, 2009] revealed that the equivalent noise level at the study area of these countries remains in between $75.2 \mathrm{~dB}$ to
$75.35 \mathrm{~dB}$, which is also higher than the prescribed standard of these all locations. The noise study at Columbia [Danie, et al., 2014] and Poland [41] only shows the Leq noise level within the prescribed standard. However, noise monitoring in Nigeria [Avwiri, and Nte., 2003] and the Philippines [Vergel et. al., 2004] shows the maximum noise level among all 22 developing countries i.e., 81.4 and $84.3 \mathrm{~dB}$, respectively. The noise monitoring was carried out in three states of India by Rajiv B. Hunashala, Yogesh B. Patil, Pervez Alam et al., and Ambika N. Joshi et al. The results show that the equivalent noise level remains maximum at Mumbai $[72.0 \mathrm{~dB}]$ followed by Delhi [70.2 dB] and Kolhapur [65.3]. Thus, the noise level of these three cities of India remains higher than the prescribed standard of Central pollution Control Board (CPCB). Furthermore, it has been found that most of the study areas of the selected developing countries have been exposed to the noise levels higher than the prescribed standard of the competent authority in the respective countries.

\section{NOISE MAPPING OF DEVELOPING COUNTRIES}

Certain locations required more detail on the noise levels than cannot be provided by a simple noise survey. Sometimes, there may be a necessity to analyze the sound pressure levels all over the place, or around a particular piece of land and machinery of industry. Noise mapping can provide the details of the noise level around any machinery, road, house or a piece of land. A noise map is a visual depiction of noise levels for a specific area and for a specific time in the form of a contour map [Hede et al., 1998]. Contours are generally colored maps to signify the intensity of noise, as well as the occurrence of low or high frequencies of noise. The map is usually overlaid on a plan of the area or workplace for which the noise mapping is required. One of the major advantages of noise mapping is to accurately assess the adverse effect of a proposed new road on the nearby structures in order for the decision-makers to take suitable noise mitigation measures to minimize the impact. This is very important in noise action planning, where a cost-benefit study of various options can be experienced before a decision is made. The authors have reviewed the noise mapping studies of 23 developing countries and 27 
Table 1. Maximum, equivalent and minimum noise level of developing countries

\begin{tabular}{|c|c|c|c|c|c|c|c|c|c|}
\hline \multirow{2}{*}{ S.No } & \multirow{2}{*}{ Author } & \multirow{2}{*}{ Country } & \multirow{2}{*}{ City } & \multirow{2}{*}{$\begin{array}{l}\text { Type of } \\
\text { study }\end{array}$} & \multirow{2}{*}{$\begin{array}{l}\text { Data } \\
\text { Source }\end{array}$} & \multirow{2}{*}{$\begin{array}{c}\text { Noise } \\
\text { measurement }\end{array}$} & \multicolumn{3}{|c|}{ Noise levels (dB A) } \\
\hline & & & & & & & Lmax & Leq & Lmin \\
\hline 1. & Chowdhury et,al., 2010 & Bangladesh & Dhaka & $\begin{array}{l}\text { Field } \\
\text { Survey }\end{array}$ & Journal & Yes & 87 & 82.0 & 53 \\
\hline 2. & Bengang et.al., 2002 & China & Beijing & $\begin{array}{l}\text { Field } \\
\text { Survey }\end{array}$ & Journal & Yes & 87.3 & 75.2 & - \\
\hline 3. & Zannin, 2002 & Brazil & Curitiba & $\begin{array}{l}\text { Field } \\
\text { Survey }\end{array}$ & Journal & Yes & - & 75.6 & - \\
\hline 4 & Ghatass, 2009 & Egypt & Alexandria & $\begin{array}{l}\text { Field } \\
\text { Survey }\end{array}$ & Journal & Yes & 47.7 & 75.6 & 98.7 \\
\hline 5. & $\begin{array}{l}\text { Essandoh and } \\
\text { Frederick, } 2011\end{array}$ & Ghana & Cape Coast & $\begin{array}{l}\text { Field } \\
\text { Survey }\end{array}$ & Journal & Yes & 87.3 & 73.5 & 51.1 \\
\hline 6. & Galindo, et al., 2017 & Colombia & Santa Marta & $\begin{array}{l}\text { Field } \\
\text { Survey }\end{array}$ & Journal & Yes & 76.04 & 64.0 & 54.8 \\
\hline 7. & Daniel et al., 2014 & Colombia & Bagota & $\begin{array}{l}\text { Field } \\
\text { Survey }\end{array}$ & Journal & Yes & 65.3 & 56.5 & 45.7 \\
\hline 8. & Mesfin, et.al., 2018 & Ethiopia & $\begin{array}{l}\text { Dire-Dawa } \\
\text { City }\end{array}$ & $\begin{array}{l}\text { Field } \\
\text { survey }\end{array}$ & Journal & Yes & 68.08 & - & 52.26 \\
\hline 9. & Abankwa, et al., 2017 & Ghana & Kumasi & $\begin{array}{l}\text { Field } \\
\text { survey }\end{array}$ & Journal & Yes & 83.5 & 72.6 & 66.8 \\
\hline 10. & $\begin{array}{l}\text { Hunashala and Patil, } \\
2012\end{array}$ & India & Kolhapur & $\begin{array}{l}\text { Field } \\
\text { Survey }\end{array}$ & Journal & Yes & 73.7 & 65.3 & - \\
\hline 11. & Akhtar et al., 2016 & India & Delhi & $\begin{array}{l}\text { Field } \\
\text { Survey }\end{array}$ & Journal & Yes & 79.3 & 70.2 & $60.2^{\circ}$ \\
\hline 12 & Joshi, et.al., 2015 & India & Mumbai & $\begin{array}{l}\text { Field } \\
\text { Survey }\end{array}$ & Journal & Yes & 80.6 & 72.0 & 64.5 \\
\hline 13. & Sondakh et. al., 2014 & Indonesia & \begin{tabular}{|l|} 
Ratulangi \\
Manado \\
\end{tabular} & $\begin{array}{l}\text { Field } \\
\text { Survey }\end{array}$ & Journal & Yes & 87.4 & 71.6 & 49.2 \\
\hline \multirow[t]{12}{*}{14.} & Biglari et al., 2016 & Iran & Tehran & $\begin{array}{l}\text { Field } \\
\text { survey }\end{array}$ & Journal & Yes & 102.57 & 75.3 & 66.7 \\
\hline & Rauf et al., 2015 & Iraq & Sulaimani & $\begin{array}{l}\text { Field } \\
\text { survey }\end{array}$ & Journal & Yes & 75.5 & 65.3 & 55.4 \\
\hline & $\begin{array}{l}\text { Awadhi and kandari, } \\
2017\end{array}$ & Kuwait & Kuwait City & $\begin{array}{l}\text { Field } \\
\text { Survey }\end{array}$ & Journal & Yes & 82.0 & 80.0 & 70.5 \\
\hline & Aziz et al., 2012 & Iraq & Erbil & $\begin{array}{l}\text { Field } \\
\text { Survey }\end{array}$ & Journal & Yes & 85.0 & 75.2 & 69.1 \\
\hline & Fernandez et. al., 2013 & Maxico & Maxico City & $\begin{array}{l}\text { Field } \\
\text { Survey }\end{array}$ & Journal & Yes & 80.1 & 77.2 & 58.1 \\
\hline & Avwiri, and Nte., 2003 & Nigeria & Nigeria Delta & $\begin{array}{l}\text { Field } \\
\text { Survey }\end{array}$ & Journal & Yes & 93.2 & 81.4 & 68.3 \\
\hline & Vergel et. al., 2004 & Philippine & Quezon City & $\begin{array}{l}\text { Field } \\
\text { Survey }\end{array}$ & Journal & Yes & 95.6 & 84.3 & 70.1 \\
\hline & Vasilyev et. al., 2017 & Russai & Samara & $\begin{array}{l}\text { Field } \\
\text { Survey }\end{array}$ & Journal & Yes & 80.1 & 65.3 & 52.0 \\
\hline & Zytoon, 2016 & Saudi Arabia & Jeddah & $\begin{array}{l}\text { Field } \\
\text { Survey }\end{array}$ & Journal & Yes & 70.1 & 62.3 & 50.5 \\
\hline & Vasilyev, 2017 & Russia & Samara & $\begin{array}{l}\text { Field } \\
\text { Survey }\end{array}$ & Journal & Yes & 65.6 & 59.8 & 46.2 \\
\hline & Çoban et al., 2018 & Turkey & Turkey City & $\begin{array}{l}\text { Field } \\
\text { survey }\end{array}$ & Journal & Yes & 76.2 & 61.3 & 52.5 \\
\hline & $\begin{array}{l}\text { Szopinska and Rącka, } \\
2017\end{array}$ & Poland & Polish City & $\begin{array}{l}\text { Field } \\
\text { Survey }\end{array}$ & Journal & Yes & 68.9 & 57.3 & 47.3 \\
\hline
\end{tabular}

cities for around two decades to demonstrate the current state of the noise mapping studies in developing countries and the gaps in the studies. Table 2 shows the assessment of 2D and 3D noise mapping of developing countries. In India [Tiwari et al., 2017; Akhtar et al., 2016] performed the 2D and 3D noise mapping for Gujarat and Delhi, using ArcView and soundPlan software, respectively. Using 2D noise mapping in Gujarat, Tiwari et al. were able to establish a critical location where remedial measures are required to reduce the adverse effect of noise on human beings. Furthermore, [Nasim Akhtar et al., 2016] has also developed 2D as well as 3D noise maps for selected locations of Delhi. Their study shows the importance of a 3D noise map, as using 3D 
mapping enables to locate the effects of noise pollution in $\mathrm{X}, \mathrm{Y}$ and $\mathrm{Z}$ direction on any residential building or setup. Most of the researchers used GIS as a tool for development of 2D noise map in different countries like Taiwan, Netherlands, Russia, Poland, Turkey, Kenya, Spain, Nigeria, Portugal and Egypt. In some countries, researchers used other tools for the development of noise maps; for instance, Nasim Akhter et al. (in India), and Zannin et al. (In Brazil) used soundPlan for the development of 2D and 3D mapping. In China, [Wu, et al., 2018] used Swallow sound for the development of a 2D noise map for the selected locations. In Latin America [Fiedler and Zannin, 2015], used Predictor 8.11 for the development of 2D and 3D noise mapping for the selected location of the Curitiba city. CAD 3D software has also been used in two countries i.e., in Spain and Brazil, in Madrid and Brasilia, respectively, for the $2 \mathrm{~d}$ noise mapping only. Most of the researchers have developed 2D noise maps only for the selected locations of different countries such as [Kartikey Tiwari et al., 2017] for India, [Tsai et al., 2009] for Taiwan, [Paulo and David, 2011] for Brazil, [Wu, 2015] for China, [Vasilyev, 2017] for Russia, [Awadhi and Kandary, 2017] for Kuwait, [Dursun et. al., 2006] for Turkey, Brainard et al., 2004 for United Kingdom, [Wawa and Mulaku, 2009] for Kenya, [Arana et al. 2009] for Spain, [Coelho and Alarcao, 2005] for Portugal, [Eldien, 2009] for Egypt, [Nicolas et al., 2016] for Chile, [Olayinka, 2012] for Nigeria, and [Farcaş and Sivertunb, 2015] for Sweden. Few researchers have developed 3D noise maps for a selected location of some countries, such as [Nasim Akhtar et al., 2016] for India, [Stoter et al., 2008] for the Netherlands, [Kossakowski, 1990] for Poland, [Fiedler and Zannin, 2015] for Latin America. As per the above literature review of $2 \mathrm{D}$ and $3 \mathrm{D}$ noise mapping, it has been established that the 2D noise maps have been developed by most of the researchers for their respective developing countries to find out the distribution of noise along a central line of a road or along the periphery of an industry. However, the literature survey also shows that the 3D noise gives a clear picture of the noise distribution in all three directions $\mathrm{X}, \mathrm{Y}$, and $Z$. In one of the studies of India, 3D noise maps have been developed by [Akhtar, et al., 2016] for the selected location of Delhi which gives clear picture of noise distribution in all three directions and also provides a number of the people affected in a particular residential building. Thus, from the review of noise mapping it can be concluded that the $2 \mathrm{D}$ noise mapping is an effective way to show the noise level distribution along with any source of noise in $\mathrm{X}$ and $\mathrm{Y}$ direction only. The 3D noise mapping is more effective than $2 \mathrm{D}$ in the residential areas, as it can also provide noise exposure level in the $\mathrm{Z}$ direction and also gives a number of people affected in high rise residential buildings. The review also shows that very few research works has been performed in the field of 3D noise mapping. On the other hand, 2D noise mapping has been used extensively by researchers.

\section{NOISE PREDICTION MODELS STUDY}

Noise prediction is one of the essential tools for decision-makers to reduce the adverse effect of noise and their control. The prediction models are generally used by three major sections of society.

1. Acoustic Engineers: Acoustical engineers are generally worried about the plan, investigation, and control of sound.

2. Acoustic specialist: They are generally part of the team to prepare an environmental impact assessment report.

3. Decision maker: Prediction models are generally used by decision-makers to identify the distribution of noise in the upcoming days.

This procedure is a unique way, after the directives by ministries, to control the environmental noise, wherein noise maps have been suggested for transportation sources and urban agglomerations. Consequently, many logical sound prediction models have been created as of late, focusing on this angle and presenting only source outflow and sound engendering observational details. Lots of prediction models have been developed and validated by researchers for their respective countries. They have been successfully used by various agencies for the development of noise maps. Aside from the source interpretation, progressed numerical strategies including wave condition and equation of continuity are utilized to resolve the sound engendering impacts. Thus, it is very important to logically investigate and compare these models so as to discover their reasonableness by and large and furthermore to discover the best methodology among them for traffic noise modeling. [Steele, 2001] conducted a thorough review of the major traffic noise models 
Table 2. Assessment of 2D and 3D noise mapping of developing countries

\begin{tabular}{|c|c|c|c|c|c|c|c|c|c|}
\hline \multirow[b]{2}{*}{ S.No } & \multirow[b]{2}{*}{ Author } & \multirow[b]{2}{*}{ Country } & \multirow[b]{2}{*}{ City } & \multirow{2}{*}{$\begin{array}{l}\text { Type of } \\
\text { study }\end{array}$} & \multirow{2}{*}{$\begin{array}{l}\text { Data } \\
\text { Source }\end{array}$} & \multirow[b]{2}{*}{ Software Used } & \multicolumn{3}{|c|}{ Noise Mapping } \\
\hline & & & & & & & $2 \mathrm{D}$ & $3 \mathrm{D}$ & $\begin{array}{c}2 \mathrm{D} \text { and } \\
3 \mathrm{D}\end{array}$ \\
\hline 1. & Tiwari et al., 2017 & India & Gujarat & $\begin{array}{l}\text { Field } \\
\text { Study }\end{array}$ & Journal & $\begin{array}{l}\text { ArcView or } \\
\text { ArcGIS }\end{array}$ & Yes & - & - \\
\hline 2. & Akhtar et al., 2016 & India & Delhi & $\begin{array}{l}\text { Field } \\
\text { Study }\end{array}$ & Journal & SoundPlan & Yes & Yes & Yes \\
\hline 3. & Tsai et. al., 2009 & Taiwan & Tainan & $\begin{array}{l}\text { Field } \\
\text { Study }\end{array}$ & Journal & GIS & Yes & - & - \\
\hline 4. & Stoter et. al., 2008 & Netherlands & Delft & $\begin{array}{l}\text { Field } \\
\text { study }\end{array}$ & Journal & GIS & Yes & Yes & Yes \\
\hline 5. & Paulo and David, 2011 & Brazil & Brazil & $\begin{array}{l}\text { Field } \\
\text { study }\end{array}$ & Journal & CAD and GIS & Yes & - & - \\
\hline 6. & Wu, et al., 2015 & China & Hnagzhou & $\begin{array}{l}\text { Field } \\
\text { Study }\end{array}$ & Journal & Swallow sound & Yes & - & - \\
\hline 7. & Wang et al., 2018 & China & Guangzhou & $\begin{array}{l}\text { Field } \\
\text { Study }\end{array}$ & Journal & ArcGIS & yes & - & - \\
\hline 8. & Vasilyev, 2017 & Russia & Samara & $\begin{array}{l}\text { Field } \\
\text { Study }\end{array}$ & Journal & GIS & Yes & - & - \\
\hline 9. & Kossakowsk, 1990 & Poland & KUT & $\begin{array}{l}\text { Field } \\
\text { Study }\end{array}$ & Journal & GIS & Yes & Yes & Yes \\
\hline 10. & $\begin{array}{l}\text { Awadhi and Kandary, } \\
2017\end{array}$ & Kuwait & Kuwait City & $\begin{array}{l}\text { Field } \\
\text { Study }\end{array}$ & Journal & CUSTIC 2.0 & Yes & - & - \\
\hline 11 & Dursun et al., 2006 & Turkey & Konya & $\begin{array}{l}\text { Field } \\
\text { Study }\end{array}$ & Journal & GIS & Yes & - & - \\
\hline 12. & Casas et al., 2014 & Brazil & Brasil & $\begin{array}{l}\text { Field } \\
\text { Study }\end{array}$ & Journal & CAD 3D & Yes & - & - \\
\hline 13. & $\begin{array}{l}\text { Yilmaz and Hocanli, } \\
2006\end{array}$ & Turkey & Sanliurfa & $\begin{array}{l}\text { Field } \\
\text { Study }\end{array}$ & Journal & GIS & Yes & - & - \\
\hline 14. & Zannin et al., 2013 & Barazil & Parana & $\begin{array}{l}\text { Field } \\
\text { Study }\end{array}$ & Journal & SoundPlan & Yes & - & - \\
\hline 15. & Brainard et al., 2004 & UK & Birmingham & $\begin{array}{l}\text { Field } \\
\text { Study }\end{array}$ & Journal & Lima & Yes & - & - \\
\hline 16. & Wawa and Mulaku, 2009 & Kenya & Nairobi & $\begin{array}{l}\text { Field } \\
\text { Study }\end{array}$ & Journal & GIS & Yes & - & - \\
\hline 17. & Arana et. al., 2009 & Spain & Pamplona & $\begin{array}{l}\text { Field } \\
\text { Study }\end{array}$ & Journal & GIS & Yes & - & - \\
\hline 18. & $\begin{array}{l}\text { Coelho and Alarcao, } \\
2005\end{array}$ & Portugal & Lisbon & $\begin{array}{l}\text { Field } \\
\text { Study }\end{array}$ & Journal & GIS & Yes & - & - \\
\hline 19. & Eldien, 2009 & Egypt & Suez city & $\begin{array}{l}\text { Field } \\
\text { Study }\end{array}$ & Journal & GIS tool & Yes & - & - \\
\hline 20. & Coelho et al., 2005 & Portugal & Odivelas & $\begin{array}{l}\text { Field } \\
\text { Study }\end{array}$ & Journal & GIS & Yes & - & - \\
\hline 21. & Nicolas et al., 2016 & Chile & Valdivia & $\begin{array}{l}\text { Field } \\
\text { Study }\end{array}$ & Journal & RLS-90 & Yes & - & - \\
\hline 22. & Olayinka, 2012 & Nigeria & \begin{tabular}{|l|} 
Ilorin \\
metropolis
\end{tabular} & $\begin{array}{l}\text { Field } \\
\text { Study }\end{array}$ & Journal & GIS & Yes & - & - \\
\hline 23. & $\begin{array}{l}\text { Kliucininkas and } \\
\text { Saliunas; } 2006\end{array}$ & UK & Kaunas & $\begin{array}{l}\text { Field } \\
\text { Study }\end{array}$ & Journal & GIS & Yes & - & - \\
\hline 24. & Kalipci and Dursun, 2009 & Turkey & Giresun & $\begin{array}{l}\text { Field } \\
\text { Study }\end{array}$ & Journal & GIS & Yes & - & - \\
\hline 25. & \begin{tabular}{|l|} 
Merchan and \\
Balteiro,2013 \\
\end{tabular} & Spain & Madrid & $\begin{array}{l}\text { Field } \\
\text { Study }\end{array}$ & Journal & CAD and GIS & Yes & - & - \\
\hline 26. & Fiedler and Zannin, 2015 & $\begin{array}{l}\text { Latin } \\
\text { America }\end{array}$ & Curitiba's & $\begin{array}{l}\text { Field } \\
\text { Study }\end{array}$ & Journal & Predictor 8.11 & Yes & Yes & Yes \\
\hline 27. & $\begin{array}{l}\text { Farcaş and Sivertunb, } \\
2015\end{array}$ & Sweden & $\begin{array}{l}\text { Skane } \\
\text { region }\end{array}$ & $\begin{array}{l}\text { Field } \\
\text { Study }\end{array}$ & Journal & ArcGIS & Yes & - & - \\
\hline
\end{tabular}

in 2001, but some of them have been revised between 2007-2013 and updated by [Garg and Maji, 2014] in 2014. Now, they have been around for six years; thus, it is imperative to update the comparison done by Garg and Maji again. The present study reviews the implication and strategies of the recently developed models such as CoRTN, Start and Stop, FHWA, etc. 


\section{FHWA Traffic Noise Model Version 3.0 (2016)}

Federal Highway Administration (FHWA) Traffic Noise Prediction Model [Anon, 1978] was developed for the United States of America (USA) Department of Transportation Federal Highway administration by Barry and Reagan (1976); they received help from preceding National Cooperative Highway Research Program (NCHRP) [Anon, 1976]. The prediction noise model was published as a Report No. FHWARD-77-108 which included calculation and programmable program. The reference noise level is the maximum noise level of the vehicle, emitted by the vehicle passed at a distance of $15 \mathrm{~m}$. In the FHWA model, Leq (Near) and Leq (Far) were calculated and the average of far and near were taken into consideration for noise average Leq noise level.

$$
\mathrm{L}_{\text {eq (near) }}=10 \log \left(\sum \text { alli } 10^{\mathrm{Leq}(\text { hi) (near)/10) }}\right.
$$

where $L e q_{(\text {near) }}=$ Noise level of all classes of vehicles from the near side of the road

$L e q_{(\text {hi })(\text { near) }}=$ The noise level of vehicle class-I from near side of the road

Leq $_{(\text {far): }} 10 \log \sum$ alli $10^{\text {Leq (hi) (far)/10) }}$

where: $L e q_{(\text {far) }}=$ Noise level of all classes of vehicles from the far side of the highway $L e q_{(h i)(f a r)}=$ Noise level of vehicle class I from the far side of the highway

$$
\mathrm{L}_{\text {eq(hourly) }}=\mathrm{ELi}+\mathrm{A}_{\text {(traffic) }}+\mathrm{A}_{\mathrm{d}}+\mathrm{A}_{\mathrm{s}}
$$

where: $A_{\text {(traffic) }}=$ Correction for traffic flow

$A_{d}=$ Correction for distance between the roadway and receiver

$A_{s}=$ Correction for all shielding and ground effects between the roadway and the receiver.

\section{Assumption for noise prediction (FHWA)}

The following are the major assumption for the prediction of the noise level by FHWA

1 . The vehicles will be represented as an acoustic source .

2. Noise emission levels will be assumed as group noise source such as (Bus, medium and heavy trucks) are normally distributed.

3. Noise propagation losses will be adequately represented by the effect of distance.
Input Parameters required for prediction of noise level (FHWA)

For validating the FHWA model, traffic noise monitoring, the characteristics of traffic, including its composition and volume of traffic on the road, are required. For the FHWA model, traffic composition is normally divided into each type of vehicle such as medium truck, heavy truck and passenger car. The light vehicles included personal cars, local taxis, vans, and motorized twowheelers, while trucks and buses are included as the heavy vehicles.

\section{RLS-90 model}

RLS90 is an efficient model, able to determine the noise pollution level of road traffic and, in current days, is the main appropriate calculation method used in Germany. It is a German national model for the prediction of road traffic noise and parking noise. It is made up of two different models; the first corresponds to the determination of noise level emission (Lme) at a distance of $25 \mathrm{~m}$ from the center of the road and $4 \mathrm{~m}$ above the ground level. Lme is determined by taking into consideration traffic such as the speed of the vehicle, distribution of the vehicle, road surface condition. The sound pressure level for a street:

$$
\mathrm{L}_{\mathrm{T}}=\mathrm{Lm}+\mathrm{K}
$$

where: $L m=$ mean A-weighted noise level

$K=$ Addition for increase in noise due to effect of traffic signal controlled intersections and other intersections

$$
\mathrm{L}_{\mathrm{me}}=\mathrm{L}_{25}+\mathrm{Cs}+\mathrm{C}_{\mathrm{rs}}+\mathrm{C}_{\mathrm{g}}+\mathrm{C}_{\mathrm{r}}
$$

where: $L_{25}=$ Standardized noise level for assumption of a speed amounting to $100 \mathrm{~km} / \mathrm{h}$ for cars and $80 \mathrm{~km} / \mathrm{h}$ for trucks.

$C_{s}=$ Speed correction

$C_{r s}^{s}=$ Road surface correction

$C_{g}=$ Gradient correction

$\stackrel{g}{C_{r}}=$ Multiple reflection correction

$$
\mathrm{L}_{25}=37.5+10 \times \log 10[\mathrm{M} \times(1+0.082 \times \mathrm{P})]
$$

where: $M=$ Number of vehicles $\left(\mathrm{h}^{-1}\right)$

$P=$ tracks exceeding $2800 \mathrm{~kg}(\%)$

The second model is for the transmission stage, in which, the noise level at a definite location is determined by making the suitable 
addition of all the contributions carried out by the sources taking into account the length of the road, the reduction of noise due to the distance, air absorption, and sound propagation due to the temperature gradient.

\section{Assumption for noise prediction (RLS-90)}

The following are the major assumption for the prediction of noise level by the RLS-90 model

1. The day and night time has been assumed as 6 $\mathrm{AM}$ to $10 \mathrm{PM}$ and $10 \mathrm{PM}$ to $6 \mathrm{AM}$, respectively.

2. It will take into account the major features which influence the noise propagation, such as obstacles, vegetation, absorption, reflections and diffraction [Quartieri et al., 2012 ].

3. Parking spots and the number of vehicles in parking spots will be considered for noise prediction.

\section{Input Parameters required for noise prediction (RLS-90)}

Prediction of the noise level by RLS- 90 required some input parameters such as the average hourly flow of traffic, separated two-wheelers, light and heavy motor vehicles, the average speed for each group of traffic, road dimension, the geometry of road and road type and any natural and artificial obstacles. This model considers the fundamental highlights which impact the propagation of noise, for example, obstacles, vegetation, reflections, and diffraction. Specifically, it makes checking the noise decrease created by obstacles conceivable and likewise considers the reflections delivered by the screens.

\section{Stop and Go model}

Pamanikabud and Tharasawatpipat [1999] of the Urban Transport Department in 1997 developed the Stop and Go model for the central part of Bangkok. The model gives emphasis on formulating an empirical model of the intermittent flow of traffic in Bangkok using two analytical approaches. The first is the single model analysis and the second is the separate lane analysis or dual model analysis. Traffic noises due to interrupted or stop and go flow of traffic situation on urban roads create considerably diverse noise

$$
\begin{gathered}
\text { Volume of traffic }= \\
=(\mathrm{AU})+1.04(\mathrm{LT})+11.12(\mathrm{MT}+\mathrm{TT})+ \\
+1.14(\mathrm{HT})+1.09(\mathrm{MC}+\mathrm{BU}+\mathrm{MB})
\end{gathered}
$$

where: $M C=$ Motorcycles

$M T=$ Medium truck

$B U=\mathrm{Bus}$

$T T=$ Tuk-Tuk

$M B=$ Minibus

The single Stop and Go model approach has been firstly applied to build a single stop and go traffic flow, noise model. This model can be used to both sides of an urban roadway. The Leq by Stop and Go single-lane model can be predicted by:

$$
\begin{aligned}
& L \text { eq }=71.05+0.10 S n+0.95 \log V n+ \\
& +0.04 S f+0.015 \log V f-0.111 D g
\end{aligned}
$$

where: $D g$ - Geometric mean of road section $(\mathrm{m}) ;=\sqrt{(\mathrm{Df}} \times \mathrm{Dn})$

In a separate lane model, the Leq noise level for acceleration and deceleration lane are taken into consideration and the average of both lanes remains the actual Leq level. The equation mentioned below is generally used for the determination of Leq by a separate lane model.

Acceleration lane Stop and Go separate lane model

$$
\begin{gathered}
\mathrm{Leq}=56.91+0.09 \mathrm{Sn}(\mathrm{a})+5.22 \log \mathrm{Vn}(\mathrm{a})+ \\
+0.04 \mathrm{Sf}(\mathrm{a})+0.02 \log \mathrm{V}(\mathrm{a})-0.006 \mathrm{D}(\mathrm{a})
\end{gathered}
$$

Deceleration lane Stop and Go separate lane model

$$
\begin{gathered}
\text { Leq }=71.12+0.07 \mathrm{Sn}(\mathrm{b})+0.42 \log \mathrm{Vn}(\mathrm{b})+ \\
+0.08 \mathrm{Sf}(\mathrm{b})+0.44 \log \mathrm{V}(\mathrm{b})-0.061 \mathrm{D}(\mathrm{b})
\end{gathered}
$$

\section{Assumption for noise prediction (Stop and Go Model)}

For the prediction of noise characteristics for interrupting traffic flow, the Stop and Go model is used. This model is based on the following assumption.

1. Two modes of vehicles motion

a) Cruising with a steady uniform speed of traffic

b) Stopping of traffic

2. The road is a straight, good surface condition, no variation

3. No noise barrier between the observer and the noise source

4. Traffic noise is measured in equivalent noise level (Leq)

5. Background noise should not exceed more than $10 \mathrm{~dB}(\mathrm{~A})$. 
Input Parameters required for prediction of noise (Stop and Go Model)

Several parameters are required while predicting noise using the stop and go model. The parameters considered are vehicle volume classified into the different vehicle types appearing on the both sides of the road, average spot speed of vehicles in the traffic stream and roadway width.

\section{CoRTN Model}

The noise prediction model CoRTN has been developed by Delany, Harland, Hood, and Scholes for the United Kingdom (UK) Department of Environmental Engineering [Steele, 2001]. It is generally used as assistance for the design of the road, and also for the prediction of noise level around a noise source. CoRTN assumes a line source and constant speed of traffic, and in the UK it is the only tool for the classification of environmental impact due to the road traffic. Calculation of Road Traffic Noise (CoRTN) [Anon, 1975] has been replaced by a handier, Predicting Road Traffic Noise (PRTN) which also followed [Delany et. al., 1976] rationale for the procedure. The noise level (predicted or measured) is expressed in terms of L10 (hourly) dB (A) and L10 (18-hour) dB (A): 6:00 to 24:00 hrs. If traffic data has been available hourly, then CoRTN can be used to produce the hourly values of $L(A) 10$ which can then be converted to Leq (A) hourly values. However, for the non-motorway roads when hourly traffic flows are below 200 vehicles per hour during the period 24:00 to 06:00 hours, the following should be used:

$$
\text { Leq(A), hourly }=0.57 * \text { L10(A), } 1 \mathrm{~h}+24.46 \mathrm{~dB}
$$

For motorways Leq may be calculated using the formula below:

$$
\begin{aligned}
& \mathrm{L}(\text { Day })=0.98 \mathrm{X} \mathrm{L}_{10}, 18 \mathrm{~h}+0.090 \mathrm{~dB} \\
& \mathrm{~L}(\text { Evening })=0.89 \mathrm{X} \mathrm{L}_{10}, 18 \mathrm{~h}+5.080 \mathrm{~dB} \\
& \mathrm{~L}(\text { Night })=0.87 \mathrm{X} \mathrm{L}_{10}, 18 \mathrm{~h}+4.240 \mathrm{~dB} \\
& \mathrm{~L}(\text { Den })=0.90 \mathrm{X} \mathrm{L}_{10}, 18 \mathrm{~h}+9.690 \mathrm{~dB}
\end{aligned}
$$

For Non motorways the Leq may be calculated using below mention formula

$$
\begin{aligned}
& \mathrm{L}(\text { Day })=0.95 \mathrm{X} \mathrm{L}_{10}, 18 \mathrm{~h}+1.44 \mathrm{~dB} \\
& \mathrm{~L}(\text { Evening })=0.97 \mathrm{X} \mathrm{L}_{10}, 18 \mathrm{~h}-2.87 \mathrm{~dB} \\
& \mathrm{~L}(\text { Night })=0.90 \mathrm{X} \mathrm{L}_{10}, 18 \mathrm{~h}-3.77 \mathrm{~dB} \\
& \mathrm{~L}(\text { Den })=0.92 \mathrm{X} \mathrm{L}_{10}, 18 \mathrm{~h}+4.20 \mathrm{~dB}
\end{aligned}
$$

\section{Assumption for noise prediction (CoRTN)}

The following parameters have been assumed during noise level prediction.

1. The source height should be $0.5 \mathrm{~m}$ above the carriage level.

2. Source distance should be $3.5 \mathrm{~m}$ from the near side carriageway edge

3. Noise has been estimated at 1 meter in front of the most exposed part of an external window or door.

4. Meteorological conditions are not taken into consideration.

5. No background noise is taken into consideration.

\section{Input Parameters required for noise prediction (CoRTN)}

For validating the CoRTN model, traffic noise monitoring, characteristics of traffic including its composition, the volume of traffic, and vehicle speed on the road have been recorded. In the process of validation, the CoRTN model and traffic composition are normally divided into the light and heavy vehicles. For this study, the light vehicles included personal cars, local taxis, vans, and motorized two-wheelers, while trucks and buses are included as the heavy vehicles.

\section{COMPARISON OF MODELS}

A comparison of different aspects of principal traffic noise prediction models was shown in Table 3. The main aspects of FHWA-TNM, RLS90, Stop and Go (Single Lane Model) and Stop and Go (Separate Lane Model) were discussed in the table. Only the Stop and Go model is predicting noise level for interrupting traffic flow. In turn, all remaining models are designed to predict the noise level for uninterrupted traffic flow. In India, the traffic flow is usually interrupted. Thus, the traffic noise model able to predict the noise level in such a complex scenario is still pending to design.

\section{CONCLUSION}

This paper reviews the literature on noise monitoring, noise mapping and noise modeling studies carried out in different countries by many researchers. Accordingly, the following conclusions were drawn. 
Table 3. Comparison of noise prediction models

\begin{tabular}{|c|c|c|c|c|c|}
\hline Model & FHWA- TNM & RLS-90 & $\begin{array}{c}\text { Stop and Go } \\
\text { (Single Lane Model) }\end{array}$ & $\begin{array}{c}\text { Stop and Go } \\
\text { (Separate Lane Model) }\end{array}$ & CoRTN \\
\hline Country & $\begin{array}{c}\text { United State of } \\
\text { America }\end{array}$ & Germany & Thailand (Bangkok) & Thailand (Bangkok) & $\begin{array}{c}\text { United } \\
\text { Kingdome }\end{array}$ \\
\hline Equation & 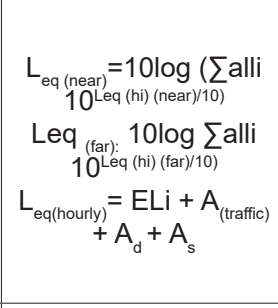 & $\begin{array}{c}L_{T}=L m+K \\
L_{m e}=L_{25}+C s \\
+C_{r s}+C_{g}+C_{r}\end{array}$ & $\begin{array}{l}\text { Leq }=71.05+0.10 S n+ \\
0.95 \log V n+0.04 S f+ \\
0.015 \log V f-0.111 D g\end{array}$ & $\begin{array}{c}\operatorname{Leq}_{\text {(Acc) }}=56.91+ \\
0.09 S n(a)+5.22 \text { Log } \\
\operatorname{Vn}(a)+0.04 S f(a)+0.02 \\
\log \vee(a)-0.006 D(a) \\
\\
\operatorname{Leq}_{(\text {dec }}=71.12+ \\
0.07 S n(b)+0.42 \text { Log } \\
V n(b)+0.08 S f(b)+0.44 \\
\log \vee(b)-0.061 D(b)\end{array}$ & $\begin{array}{l}\text { Leq }(A), \text { hourly }= \\
0.57^{\star} L_{10}(A), 1 \mathrm{~h}+ \\
24.46 \mathrm{~dB}\end{array}$ \\
\hline $\begin{array}{l}\text { Traffic } \\
\text { Condition }\end{array}$ & Constant, Grades & $\begin{array}{l}\text { Acceleration, } \\
\text { Uniform } \\
\text { speed, } \\
\text { intermittent } \\
\end{array}$ & Uniform Speed & $\begin{array}{l}\text { Acceleration, Uniform } \\
\text { speed, }\end{array}$ & Uniform Speed \\
\hline $\begin{array}{l}\text { Data } \\
\text { Requirement }\end{array}$ & $\begin{array}{l}\text { Speed of Traffic, } \\
\text { Traffic Flow, } \\
\text { Environment } \\
\text { Condition and } \\
\text { Local } \\
\text { characteristics }\end{array}$ & $\begin{array}{l}\text { Traffic type, } \\
\text { Traffic Flow,, } \\
\text { Road data, } \\
\text { and } \\
\text { Environment } \\
\text { Condition and } \\
\text { Local } \\
\text { characteristics } \\
\end{array}$ & $\begin{array}{l}\text { Type of traffic, Detail of } \\
\text { interrupted flow, speed } \\
\text { of traffic and road } \\
\text { geometry }\end{array}$ & $\begin{array}{l}\text { Type of traffic, Detail of } \\
\text { interrupted flow, speed of } \\
\text { traffic(Acceleration and } \\
\text { deceleration lane) and } \\
\text { road geometry }\end{array}$ & $\begin{array}{l}\text { Heavy to Light } \\
\text { vehicle } \\
\text { Ration, Low, } \\
\text { speed, road } \\
\text { and environs } \\
\text { data. }\end{array}$ \\
\hline Mapping & Grid & Point & Point & Point & Grid \\
\hline Application & $\begin{array}{l}\text { Prediction road } \\
\text { Traffic noise, }\end{array}$ & $\begin{array}{l}\text { Prediction } \\
\text { road traffic } \\
\text { noise } \\
\end{array}$ & $\begin{array}{l}\text { Urban road traffic, } \\
\text { uninterrupted traffic } \\
\text { flows (Leq) }\end{array}$ & $\begin{array}{l}\text { Urban road traffic, } \\
\text { interrupted traffic flows } \\
\text { (Leq) }\end{array}$ & $\begin{array}{l}\text { Prediction of } \\
\text { Single traffic } \\
\text { noise }\end{array}$ \\
\hline Limitations & Leq only & $\begin{array}{l}\text { No local } \\
\text { characteristics } \\
\text { take cares. }\end{array}$ & $\begin{array}{l}\text { Not take care traffic } \\
\text { flow of both lanes }\end{array}$ & & $\begin{array}{l}\text { On the basis of } \\
\mathrm{L}_{10} \mathrm{~L}_{e q} \text { is being } \\
\text { determine that } \\
\text { is obsolete }\end{array}$ \\
\hline $\begin{array}{l}\text { Noise Data } \\
\text { requirement }\end{array}$ & $\begin{array}{l}\text { Equivalent Noise } \\
\text { Level and } L_{10} \text { noise } \\
\text { level }\end{array}$ & $\begin{array}{l}\text { Equivalent } \\
\text { Noise Level }\end{array}$ & $\begin{array}{l}\text { Leq, Equivalent Noise } \\
\text { Level }\end{array}$ & Equivalent Noise Level & $\mathrm{L}_{10}$ noise level \\
\hline
\end{tabular}

1. $90 \%$ noise monitoring studies focused on the traffic noise, the remaining $10 \%$ focused on the residential, commercial and industrial areas.

2. The 2D noise maps were developed by $95 \%$ of researchers only $5 \%$ developed $2 \mathrm{D}$ as well as 3D noise maps.

3. Most of the noise prediction models use uniform traffic flow for the prediction of noise levels, only a few predict the noise levels for uniform as well as interrupted flow.

4. On the basis of the above-mentioned literature survey, it has also been concluded that the noise monitoring has not been carried out in different seasons and 24 X 7 and the 3D noise maps have not been developed for the assessment of noise level. However, the 2D noise maps are readily developed for noise assessment.

\section{REFERENCES}

1. Directive 2002/49/EC of the European Parliament and of the Council of 25 June 2002 relating to the assessment and management of environmental noise (END). Brussels, the European Parliament and the Council of the European Union, 2002.

2. Mohammadi, 2009. An Investigation of Community Respond to Urban Traffic Noise. J Environment Health Science, 2, 137 .

3. Zannin, P.H.T., Engel, M.S., Fiedler, P.E.K., Bunn, F., 2013. Characterization of Environmental Noise Based on Noise Measurements, Noise Mapping and Interviews: a Case Study at a University Campus in Brazil. Cities, 31, 317.

4. Mocuta, G.E., 2012. Noise Pollution Emitted as a Consequence of the Urban Transport Development. J Environ Prot Ecol, 13 (2A), 852.

5. Eelco, L.C., Boer, D., Schroten, A., 2007. Traffic Noise Reduction in Europe. CE Delft.

6. Stoilova, K., Stoilov, T., 1998. Traffic Noise and Traffic Light Control. Transportation Research Part D: Trans Environ, 3 (6), 399.

7. Zannin, P. H. T., Calixto, A., Diniz, F. B., Ferreira, J. A. C., 2003. A Survey of Urban Noise Annoyance in a Large Brazilian City: the Importance of a Subjective Analysis in Conjunction with an Objective 
Analysis. Environ. Impact Asses, 23 (2), 245.

8. Piccolo, A., Plutino, D., Cannistraro, G., 2005, Evaluation and Analysis of the Environmental Noise of Messina, Italy. Appl Acoust, 66, 447.

9. Zannin, P.H.T., Ferreira, A.M.C., Szeremetta, B., 2006, Evaluation of Noise Pollution in Urban Parks. Environ Mon Asses, 118, 423.

10. Akhtar, N., Ahmad, K., and Alam P., 2016, Noise Monitoring and Mapping for Some Pre-selected Locations of New Delhi, India, Fluctuation and Noise Letters Vol. 15, No. 2.

11. Iliescu, M., Cadar, Y., Beca, M., 2015. Monitoring Noise Pollution in Urban Area Through SUNET System, Bulletin USAMV series Agriculture 72(1).

12. Steele, C., (2001), A critical review of some traffic noise prediction models, Applied Acoustics 62, 271-287.

13. J.E. Stoter, H. de Kluijver, V. Kurakula: 3D noise mapping in urban areas, International Journal of Geographical Information Science Vol. 22, No. 8,907-924, 2008.

14. Chang T.Y., Liu C.S., Bao B.Y., Li S.F., Chen T.I., Lin Y.J., Characterization of road traffic noise exposure and prevalence of hypertension in Central Taiwan, Science Total Environment, 409, 1053-1057, 2011.

15. Naveen Garg, A.K. Sinha, M. Dahiya, V. Gandhi R.M. Bhardwaj, A.B. Akolkar; Evaluation and Analysis of Environmental Noise Pollution in Seven Major Cities of India, Archives of Acoustics, Vol. 42, No. 2, pp. 175-188, 2017.

16. E. S. Barrekette, Pollution Springer Science Business Media New York 1973.

17. Sanjib Chandra Chowdhury, M. Mahbubur Razzaque, and Md. Maksud Helali; Assessment of Noise Pollution In Dhaka City; 17th international congress of sound and vibration, ICSV17, Cairo, Egypt, 18-22 July 2010.

18. Bengang Li, Shu Tao, R.W. Dawson; Evaluation and analysis of traffic noise from the main urban roads in Beijing; Applied Acoustics 63, 1137-1142, 2002.

19. Paulo Henrique Trombetta Zannin, Fabiano Belisario Diniz, Wiliam Alves Barbosa; Environmental noise pollution in the city of Curitiba, Brazil; Applied Acoustics 63 351-358, 2002.

20. Zekry F. Ghatass; Assessment and Analysis of Traffic Noise Pollution in Alexandria City, Egypt; World Applied Sciences Journal 6 (3): 433-441, 2009.

21. Paul K. Essandoh and Frederick Ato Armah; Determination of Ambient Noise Levels in the Main Commercial Area of Cape Coast, Ghana;

Research Journal of Environmental and Earth Sciences 3(6): 637-644, 2011.

22. Angélica Patricia Garrido Galindo, Yiniva Camargo Caicedo, Andres M Vélez-Pereira; Noise level in a neonatal intensive care unit in Santa
Marta-Colombia; Colombia Médica-Vol. 48, 2017.

23. Paez, Danie; Thirouin, Maïté; Behrentz, Eduardo; Pacheco, José; Perry, Anthony; Where Are We out? Spatial Analysis Of Noise Pollution In Bogota; conference_proceedings/Inter Noise 2014.

24. Kinfe Mesfin*, Abdrie Seid Hasen and Mohamed Birhanu; Determination of Noise Pollution Level in Dire-Dawa City, Ethiopia; Int J Environ Sci Nat Res 8(2): IJESNR.MS.ID.555733, 2018.

25. Abankwa E.O., Agyei-Agyemang A., Tawiah P.O; Impact of Noise in the Industry and Commercial areas in Ghana: Case Study of the Kumasi metropolis; Int. Journal of Engineering Research and Application; Vol. 7, Issue 7,, pp.11-19, July 2017

26. Rajiv B. Hunashal, Yogesh B. Patil, 2012. Assessment of noise pollution indices in the city of Kolhapur, India; Procedia - Social and Behavioral Sciences 37, 448-457.

27. Nasim Akhtar, Kafeel Ahmad and Pervez Alam; Noise Monitoring and Mapping for Some Pre-selected Locations of New Delhi, India; Fluctuation and Noise Letters, 15(2), 2016.

28. Ambika N. Josh, Nitesh C. Joshi, Dr. Payal P. Rane; Noise Mapping in Mumbai City, India; IJISET; 2(3), 2015.

29. Daniel Sondakh1, Maryunani, Soemarno , Budi Setiawan; Analysis of Noise Pollution on Airport Environment (Case study of International Airport of Sam Ratulangi Manado, Indonesia); International Journal of Engineering Inventions; 4(2), 2014.

30. Hamed Biglari, Mehdi Saeidi, Mohsen Poursadeghiyan, Hooshmand Sharafi, Mohammad Reza Narooie, Vali Alipour, Somayeh Rahdar, Razieh Khaksefidi, Amin Zarei, Morteza Ahamadabadi1; A Study On Noise Pollution In The City Of Tehran, Iran; International Journal of Pharmacy \& Technology; Vol., 3, 2016.

31. Kani M Rauf, Hussein Hossieni, Saro S Ahmad, Sarkhel Jamal and Aras Hussien; Comparison of the Noise Pollution in Sulaimani City between the Years 2009 and 2014;Pollution effects and control; Volume 3, Issue 1, 2015.

32. jasem M. Al-Awadhi, Dhary S. AlKandary; Mapping and Validation of Noise Level in Kuwait City; Transactions on Science and Technology Vol. 4, No. 1, 38-47, 2017.

33. Shuokr Qarani Aziz Lulusi, Faridah A.H. Asaari, Nor Azam Ramli Hamidi, Abdul Aziz Amin Mojiri and Muhammad Umar; Assessment of Traffic Noise Pollution in Bukit Mertajam, Malaysia and Erbil City, Iraq; Caspian Journal of Applied Sciences Research, 1(3), pp. 1-11, 2012.

34. Luis Pastor Sánchez Fernández, Luis A. Sánchez Pérez, José J. Carbajal Hernández; Monitoring System of Environment Noise and Pattern Recognition; Proceedings of the International Conference 
on Environment, Energy, Ecosystems and Development 2013.

35. G.O. Avwiri, F. Nte; Environmental sound quality of some selected flow Stations in the Niger delta of Nigeria; Journal of Applied Sciences and Environmental Management Vol. 7(2) 2003, 75-77

36. Karl N. Vergel, Frielly T. Cacho and Cheryl Lyne E. Capiz; A Study on Roadside Noise Generated by Tricycles; Philippine Engineering Journal, 2004; 25(2), 1-22.

37. Andrey V. Vasilyev, 2017. New methods and approaches to acoustic monitoring and noise mapping of urban territories and experience of it approbation in conditions of Samara region of Russia; Procedia Engineering 176, 669-674.

38. Mohamed A. Zytoon; Opportunities for Environmental Noise Mapping in Saudi Arabia: A Case of Traffic Noise Annoyance in an Urban Area in Jeddah City; Int. J. Environ. Res. Public Health 2016, $13,496$.

39. Nilgün Akbulut Çoban, Cengiz Dalkılıç, Sezer Kaya, Mevlüt Türkmenoğlu, and Mustafa Çoban; Smart Solutions for Recreational Noise Pollution in Turkey; Noise Mapp. 2018; 5:21-32.

40. Kinga Szopińska and Izabela Rącka; Assessment of the Sound Environment and Prices of NoiseSensitive Real Estate - Case Study of a Polish City; (ICCSEAS 2017) Paris, France on November 28-29, 2017.

41. Kartikey Tiwari, Shivendra ku. jha and Bhaven N. Tandel; GIS Based Approach for Noise Mapping of Urban Road Traffic; NAP-2017, S.V.N.I.T.

42. Nasim Akhtar, Kafeel Ahmad and Pervez Alam; Noise Monitoring and Mapping for Some Pre-selected Locations of New Delhi, India; Fluctuation and Noise Letters, 15(2), 2016.

43. Kang-Ting Tsai, Min-Der Lin, Yen-Hua Chen; Noise mapping in urban environments: A Taiwan study; Applied Acoustics 70 (2009) 964-972.

44. Jantien Stoter, Henk De Kluijver, Vinaykumar Kurakula; 3D noise mapping in urban areas; International Journal of Geographical Information Science Vol. 22, No. 8, 2008, 907-924.

45. Paulo Henrique Trombetta Zannin, David Queiroz de Sant'Ana; Noise mapping at different stages of a freeway redevelopment project - A case study in Brazil; Applied Acoustics 72 (2011) 479-486.

46. R. Wu, B. Zhang, L. Liu, J. Yang; Application of noise mapping in environmental noise management in Hnagzhou, China; Euro noise 2015, Maastricht.

47. Haibo Wang, Hanjie Chen, Ming Cai; Evaluation of an urban traffic NoiseeExposed population based on points of interest and noise maps: The case of Guangzhou; Environmental Pollution 239 (2018) 741-750.
48. Andrey V. Vasilyev; New methods and approaches to acoustic monitoring and noise mapping of urban territories and experience of it approbation in conditions of Samara region of Russia; Procedia Engineering 176 (2017) 669-674.

49. Paweł Kossakowski; Strategic Noise Maps; Environment; 1-9.

50. Jasem M. Al-Awadhi, Dhary S. Al Kandary; Mapping and Validation of Noise Level in Kuwait City; Transactions on Science and Technology Vol. 4, No. 1, $38-47,2017$.

51. Şukru Dursun, Celalettin Ozdemir, Hakan Karabörk, Saim Koçak; Noise Pollution And Map Of Konya City In Turkey; J. Int. Environmental Application \& Science; Vol. 1 (1-2): 63-72, 2006.

52. W J P Casas, E P Cordeiro, T C Mello, P H T Zannin; Noise mapping as a tool for controlling industrial noise pollution; Journal of Scientific \& Industrial Research Vol. 73, April 2014, 262-266.

53. Guzel Yilmaz and Yuksel Hocanli; Mapping of Noise By Using GIS In S,Anliurfa; Environmental Monitoring and Assessment (2006) 121: 103-108.

54. Paulo Henrique Trombetta Zannin, Vinícius Luiz Gama, Maurício Laçoni da Cunha, Eduardo Ferraz Damiani, Marcello Benetti, Henrique Bianchi, André Luiz Senko da Hora, Guilherme Bortolaz Guedes, Tiago Luiz Portella, Vitor André Jastale Pinto and David Queiros de Sant'Ana; Noise Mapping of an Educational Environment; Canadian Acoustics; 40(1), 2013, 20-27.

55. Julii S. Brainard, Andrew P. Jones, Ian J. Bateman and Andrew A. Lovett; Exposure To Environmental Urban Noise Pollution in Birmingham, UK; Urban Studies, 41(13), 2581-2600, 2004.

56. Enock Abe Wawa, Galcano Canny Mulaku; Noise Pollution Mapping Using GIS in Nairobi, Kenya; Journal of Geographic Information System, 2015, 7, 486-493.

57. Miguel Arana, Ricardo San Martín, Iñaki Nagore, David Pérez; Using Noise Mapping to Evaluate the Percentage of People Affected by Noise; Acta Acustica United With Acustica Vol. 95 (2009) 550-554.

58. J. L. Bento Coelho, Diogo Alarcao; On Noise Mapping and Noise Action Plans for Large Urban Areas; Forum Acusticum 2005 Budapest.

59. Bany Bossam Eldien; Noise Mapping In Urban Environments: Application at Suez City Center; IEEE Explore, 2009, 1722-1727.

60. J. L. Bento Celho, J. R. Mteus, M. J. Palma, A. M Almeida, C. Patcerio; Noise Mapping of road Traffic Noise in Portugal; Inter. Noise, 2000, 1-4.

61. Nicolás A. Bastián-Monarca, Enrique Suárez, Jorge P. Arenas ; Assessment of methods for simplified traffic noise mapping of small cities: Casework of the city of Valdivia, Chile; Science of the Total 
Environment 550 (2016) 439-448.

62. Oyedepo Sunday Olayinka; Noise Map: Tool for Abating Noise Pollution in Urban Areas; 2012, 1, 185.

63. L. Kliučininkas and D. Šaliūnas; Noise mapping for the management of urban traffic flows; Mechanika. 2006, 61-66.

64. E. Kalipci and S. Dursun; Presentation of Giresun city traffic noise pollution Mpa Via Geographical Information system; Journal of applied Science; 2009, 479-487.

65. Carlos Iglesias Merchan, Luis Diaz-Balteiro; Noise pollution mapping approach and accuracy on landscape scales; Science of the Total Environment 449, 2013, 115-125.

66. Paulo Eduardo Kirrian Fiedler, Paulo Henrique Trombetta Zannin; Evaluation of noise pollution in urban traffic hubs-Noise maps and measurements. Environmental Impact Assessment Review 51, 2015, 1-9.

67. Farcaş F. and Sivertunb Å. Road Traffic Noise: Gis Tools for Noise Mapping and A Case Study For Skåne Region; The International Archives of The Photogrammetry, Remote Sensing and Spatial Information Sciences, 34, 2015, 1-10.

68. A Hede, N.L. Carter, R.F.S. Job, „Environmental noise regulation: A public policy perspective", Noise as a Public Health Problem; Noise Effects; 1998, vol. 2, 687-96.

69. Chi-wing Law, Chee-kwan Lee, Aaron Shiu-wai Lui, Maurice Kwok-leung Yeung, Kin-che Lam; Advancement of three-dimensional noise mapping in Hong Kong; Applied Acoustics 72, 2011, 534-543.

70. Steele C. A critical review of some traffic noise prediction models. Applied Acoustics 2001, 62, 271-287.

71. Naveen Garg and Sagar Maji; A critical review of principal traffic noise models: Strategies and implications; Environmental Impact Assessment Review 46, 2014, 68-81.

72. Anon. FHWA. traffic noise prediction model US. Washington: Department of Transportation, Federal Highway Administration National Technical Information Service, 1978.

73. Anon. Highway noise Đ generation and control. National Cooperative Highway Research Program report 173. Washington: Transportation Research Board, 1976.

74. J. Quartieri, N.E. Mastorakis, G. Iannone, C. Guarnaccia,S. D’Ambrosio, A. Troisi, TLL Lenza 2012. A Review of Traffic Noise Predictive Models. Recent Advances In Applied and Theoretical Mechanics; Vol. 3, 72-80.

75. P. Pamanikabud and C. Tharasawatpipat (1999), Modeling of urban area stop-and-go model. Journal of Transportation Engineering; 125 (2), 257-271.

76. Campbell Steele (2001); A critical review of some traffic noise prediction models; Applied Acoustics 62, 271-287.

77. Anon. Calculation of road traffic noise. London: United Kingdom Department of the Environment and Welsh Oce Joint Publication/HMSO, 1975.

78. Anon. Predicting road traffic noise. United Kingdom Department of the Environment/HMSO, London.

79. Delany ME, Harland DG, Hood RA, Scholes WE. The prediction of noise levels L10 due to road traffic. Journal of Sound and Vibration 1976, 48(3), $305-325$. 